\title{
Tobacco waste ash: a promising supplementary cementitious material
}

\author{
Paalo Moreno ${ }^{1}\left(\right.$ D $\cdot$ Rafael Fragozo $^{1,2} \cdot$ Sergio Vesga ${ }^{1} \cdot$ Mauricio Gonzalez $^{1,2} \cdot$ Liliana Hernandez $^{1} \cdot$ Ivan D. Gamboa $^{1}$. \\ Jose Delgado ${ }^{1}$
}

Received: 20 September 2017 / Accepted: 10 April 2018 / Published online: 12 May 2018

(c) The Author(s) 2018

\begin{abstract}
According to the European Cement Association, CEMBUREAU, in 2015, the global cement production was 4.6 billion tons. Traditional cement production emits approximately 1 ton of $\mathrm{CO}_{2}$ per ton of cement, which represents almost $80 \%$ of the total $\mathrm{CO}_{2}$ emissions of concrete and approximately $6 \%$ of the world's emissions. Among supplementary cementitious materials, the use of agro-waste ash emerges due to its reduced $\mathrm{CO}_{2}$ emissions, chloride diffusion, and materials cost, in addition to its greater compressive strength. In Colombia, the disposal of agro-wastes, such as tobacco waste, is an environmental and economic concern. In this study, ash obtained from tobacco waste (TWA) was studied as a sustainable partial replacement for cement in hydraulic concrete. The TWA was reduced to a particle size of less than $75 \mu \mathrm{m}$ and was characterized by X-ray florescence. A central composite design was used to study the influence of the ash replacement percentage of cement and the water/binder $(w / b)$ ratio on the compressive strength at 28 days. The results show that it is possible to replace $10 \%$ of the cement with TWA using a $0.5 \mathrm{w} / \mathrm{b}$ ratio and obtain a $51 \%$ higher compressive strength than the control mixture at 28 days. Moreover, the experimental results demonstrated an improvement of $86 \%$ in the 7-day compressive strength when TWA was used.
\end{abstract}

Keywords Concrete $\cdot$ Tobacco waste ash $\cdot$ Supplementary cementitious material $\cdot$ Sustainable construction material . Compressive strength $\cdot$ Design of experiments

\section{Introduction}

Concrete is the most widely used material on earth, apart from water. The main binder of concrete is cement. According to the activity report published by the European Cement Association, CEMBUREAU, in 2015, the global cement production was 4.6 billion tons [1]. Traditional cement $\mathrm{CO}_{2}$ emissions are very high and, in some cases, can be more than 1 ton per 1 ton of cement production. Approximately 0.55 tons of the carbon dioxide emissions from 1 ton of cement production originate from the chemical reaction (calcination) of calcium carbonate that converts limestone $\left(\mathrm{CaCO}_{3}\right)$ to calcium oxide $(\mathrm{CaO})$. This reaction occurs at

Paalo Moreno

paaloandrea@gmail.com; pa.moreno@mail.udes.edu.co

1 Civil Engineering Department, Grupo ambiental de investigación aplicada, GAIA, Universidad de Santander UDES, Bucaramanga, Colombia

2 Organización Gonzalez Bohorquez \& Cia Ltda, Bucaramanga, Colombia
$1400{ }^{\circ} \mathrm{C}$ and requires the combustion of fossil fuels, which emits an additional 0.40 tons of greenhouse gas [2]. The cement production emissions represent almost $80 \%$ of the total $\mathrm{CO}_{2}$ emissions of concrete, which in turn, are approximately $6-7 \%$ of the planet's total $\mathrm{CO}_{2}$ emissions [3].

To reduce the $\mathrm{CO}_{2}$ emissions while maintaining the concrete properties and reducing the cement content, it is necessary to add supplementary cementitious materials (SCMs). ASTM C125-16 [4] defines a SCM as an inorganic material that contributes to the properties of a cementitious mixture through hydraulic or pozzolanic activity, or both. These materials can improve concrete properties, such as the compressive strength, durability, and impermeability, and can reduce the cost and carbon emissions as well as improve sustainability [5-7]. The reactivity of SCMs in concrete depends on the chemistry of the cement and the chemistry of the SCM, the water-to-binder ratio $(w / b)$, and the SCM replacement level [6,7]. The SCMs consist of fly ash [8], blast-furnace slag [9], silica fume [10], metakaolin [5], and ash from agricultural wastes (Table 1). 
Table 1 Cement replacement, water-to-binder ratio $(w / b)$ and normalized compressive strength using ash from different agro-waste materials

\begin{tabular}{lllll}
\hline Ash & $\begin{array}{l}\text { Cement replace- } \\
\text { ment }(\%)\end{array}$ & $w / b$ ratio & $\begin{array}{l}\text { Normalized compressive } \\
\text { strength }(\%) \text { at 28 days }\end{array}$ & References \\
\hline Sugarcane bagasse & 20 & 0.4 & 84.9 & {$[11]$} \\
Organic waste & $5-12$ & $0.35-0.45$ & $92-104$ & {$[12]$} \\
Palm oil fuel & $10-40$ & 0.35 & $89-106$ & {$[13]$} \\
Rice husk & $20-40$ & 0.50 & $98-104$ & {$[14]$} \\
Sewage sludge & $5-20$ & 0.68 & $75-90$ & {$[15]$} \\
Palm oil fuel & 20 & 0.28 & 101 & {$[16]$} \\
Rice husk & $5-20$ & 0.50 & $108-112$ & {$[17]$} \\
\hline
\end{tabular}

Table 2 Chemical requirements for class $\mathrm{N}$ pozzolanic materials (ASTM C618-15 [19])

\begin{tabular}{lc}
\hline Specification & Class $\mathrm{N}$ \\
\hline $\mathrm{SiO}_{2}+\mathrm{Al}_{2} \mathrm{O}_{3}+\mathrm{Fe}_{2} \mathrm{O}_{3}$, min, \% & 70.0 \\
$\mathrm{SO}_{3}$, max, \% & 4.0 \\
Moisture content, max, \% & 3.0 \\
Loss on ignition (LOI), max, \% & 10.0 \\
\hline
\end{tabular}

Rice husk ash is the most studied material [18]. The cement replacements studied are in the range of 5-40\%, the $w / b$ values are between 0.35 and 0.68 , and the compressive strengths when using ash from agro-waste materials as a partial cement replacement are reported to be similar to or even greater than traditional cement.

Depending on the oxides present in the ash wastes, the mineral additions could act as pozzolanic materials. Table 2 shows the chemical requirements for class $\mathrm{N}$ pozzolanic materials according to ASTM C618-15 [19]. The class N refers to raw or calcined natural pozzolans.

The term pozzolanic activity covers all reactions occurring among the active constituents of pozzolans, lime, and water. The active constituents $\left(\mathrm{SiO}_{2}, \mathrm{Al}_{2} \mathrm{O}_{3}, \mathrm{Fe}_{2} \mathrm{O}_{3}\right)$ react with calcium hydroxide $(\mathrm{CH})$ leading to an increase of calcium silicate hydrate (CSH) in the cement paste [7, 20].

Table 3 shows the main chemical components of the agrowaste ash presented in Table 1.
According to the chemical requirements (Table 3), sugarcane bagasse ash [11], rice husk ash [14, 17], and palm oil fuel ash (POFA) [16] are pozzolanic materials.

Colombia is an agricultural country, with coffee, palm oil, rice, corn, banana, sugar cane, and tobacco among its primary crops. Tobacco is grown in more than 120 countries, producing approximately 6 million tons per year. In 2016, Colombia produced 10,980 tons of tobacco [21,22]. The disposal of agro-waste materials is an environmental and economic concern, since the majority of the waste is fired and the remaining ashes are considered another waste [18].

Engineers have been challenged to convert wastes to useful construction materials to reduce their negative environmental and social impacts [23]. Using ash from agrowaste materials as SCMs has economic, environmental, and social advantages for helping sustainable development [24].

The focus of the research on SCMs has been on the exploration of alternative SCMs and their performance in concrete [7]. The goal of the present work is to study the use of tobacco waste ash (TWA) as a promising supplementary cementitious material, and the influence of the ash replacement percentage of cement and the $w / b$ ratio on the compressive strength at 28 days. The novelty and validity of this study is that, according to the authors' knowledge, no studies are available in the literature using tobacco waste ash as a SCM.

Table 3 Comparisons among the main chemical components of ash from different agro-waste materials

\begin{tabular}{|c|c|c|c|c|c|c|c|}
\hline Ash & $\mathrm{SiO}_{2}(\%)$ & $\mathrm{Al}_{2} \mathrm{O}_{3}(\%)$ & $\mathrm{Fe}_{2} \mathrm{O}_{3}(\%)$ & $\mathrm{SO}_{3}(\%)$ & LOI $(\%)$ & $\mathrm{SiO}_{2}+\mathrm{Al}_{2} \mathrm{O}_{3}+\mathrm{Fe}_{2} \mathrm{O}_{3}(\%)$ & References \\
\hline Sugarcane bagasse & 74.0 & 3.7 & 1.8 & 0.3 & 11.2 & 79.5 & {$[11]$} \\
\hline Organic waste & 37.5 & 7.8 & 5.3 & 1.0 & 16.8 & 50.6 & [12] \\
\hline Palm oil fuel & 55.7 & 0.9 & 2.0 & 2.9 & 4.7 & 58.6 & [13] \\
\hline Rice husk & 93.2 & 0.4 & 0.1 & 0.9 & 3.7 & 93.7 & {$[14]$} \\
\hline Sewage sludge & 17.3 & 9.6 & 8.5 & 9.0 & & 35.4 & [15] \\
\hline Palm oil fuel & 58.3 & 6.7 & 9.8 & 1.0 & 7.3 & 74.8 & [16] \\
\hline Rice husk & 91.8 & 2.1 & 0.8 & & 1.6 & 94.7 & [17] \\
\hline
\end{tabular}




\section{Materials and methods}

\section{Materials}

Ordinary Portland cement (OPC) Type I conforming to ASTM C150-07 [25] with a specific gravity of 3.1 was used. Dry and clean natural river sand passing through a $4.75 \mathrm{~mm}$ sieve and having a specific gravity of 2.69 was used as the fine aggregate. The coarse aggregate was crushed gravel with a maximum size of $9.5 \mathrm{~mm}$ and a specific gravity of 2.75. Both aggregates were in accordance with ASTM C33/ C33M-16 [26].

The tobacco waste was collected from a local farm, and the waste was primarily composed of tobacco stems. The ash content of the wastes was $5.5 \%$.

The waste was burned (uncontrolled), and the resulting ashes were sieved through a $425 \mu \mathrm{m}$ sieve to eliminate undesirable particles. The ashes were ground in a Los Angeles abrasion machine to reduce the particle size to $45 \mu \mathrm{m}$. The resulting ash was dark gray in color because of its high carbon content; it was further burned at $700{ }^{\circ} \mathrm{C}$ for $3 \mathrm{~h}$.

The chemical compositions of the TWA and the OPC used in this study were evaluated by X-ray fluorescence (XRF, BRUKER S8 TIGER). The TWA specific gravity was 2.68, as measured according to ASTM C188 [27].

\section{Experimental design}

The influence of the ash replacement percentage of cement and the $w / b$ ratio on the compressive strength at 28 days was tested by central composite design (CCD) experiments, as shown in Table 4. In addition, testing was performed on a control mixture with $100 \%$ cement (experiment 10).
The fine and coarse aggregate amounts were kept constant at 1025 and $905 \mathrm{~kg} / \mathrm{m}^{3}$, respectively. The amount of binder materials was $360 \mathrm{~kg} / \mathrm{m}^{3}$. To ensure homogeneity, the OPC and TWA were first mixed together. The concrete constituents were mixed in a SIEMENS concrete mixer for $5 \mathrm{~min}$.

The fresh concrete was poured into standard cylinders measuring $100 \mathrm{~mm}$ in diameter and $200 \mathrm{~mm}$ in height, in accordance with ASTM C 31/C 31M-15a [28]. The formwork was removed $24 \mathrm{~h}$ after casting. The samples were stored in lime-saturated water at $25^{\circ} \mathrm{C}$ until further testing.

\section{Compressive strength}

In this study, the compressive strength of the produced concrete mixtures was determined based on ASTM C39/C39M$16 \mathrm{~b}$ [29]. The cylinders were tested at 7 and 28 days. Each compressive strength value reported is the average of three samples.

\section{Statistical analysis}

The experimental data were evaluated using analysis of variance (ANOVA) and response surface methodology (RSM). The statistical analyses were performed using Statgraphics Centurion software (Version 16.1.18, Statpoint Inc., Herndon, VA, USA) for a $95 \%$ degree of confidence $(P<0.05)$.

\section{Results and discussion}

\section{Tobacco waste ash composition}

Table 5 shows the X-ray fluorescence results for OPC and TWA. The OPC composition conforms to ASTM C150-07

Table 4 Central composite design

\begin{tabular}{|c|c|c|c|c|c|c|c|c|c|c|}
\hline \multirow[t]{2}{*}{ No. } & \multirow[t]{2}{*}{ Cement $\left(\mathrm{kg} / \mathrm{m}^{3}\right)$} & \multicolumn{2}{|l|}{ Ash } & \multirow[t]{2}{*}{$W / B$ ratio } & \multicolumn{2}{|c|}{ Coded factors } & \multicolumn{2}{|c|}{$\begin{array}{l}\text { Compressive strength } \\
(\mathrm{MPa})\end{array}$} & \multicolumn{2}{|c|}{$\begin{array}{l}\text { Normalized com- } \\
\text { pressive strength } \\
(\%)\end{array}$} \\
\hline & & $\left(\mathrm{kg} / \mathrm{m}^{3}\right)$ & $\begin{array}{l}\% \text { Replace- } \\
\text { ment }\end{array}$ & & $A$ & $B$ & 7 days & 28 days & 7 days & 28 days \\
\hline 1 & 342 & 18 & 5 & 0.45 & -1 & -1 & $19.6 \pm 0.9$ & $25.8 \pm 1.4$ & 175 & 144 \\
\hline 2 & 342 & 18 & 5 & 0.55 & -1 & 1 & $14.6 \pm 0.7$ & $19.7 \pm 1.4$ & 130 & 110 \\
\hline 3 & 306 & 54 & 15 & 0.45 & 1 & -1 & $19.7 \pm 1.1$ & $27.0 \pm 0.3$ & 176 & 151 \\
\hline 4 & 306 & 54 & 15 & 0.55 & 1 & 1 & $13.6 \pm 0.2$ & $18.2 \pm 0.7$ & 121 & 101 \\
\hline 5 & 324 & 36 & 10 & 0.50 & 0 & 0 & $20.8 \pm 1.3$ & $27.0 \pm 0.8$ & 186 & 151 \\
\hline 6 & 342 & 18 & 5 & 0.50 & -1 & 0 & $17.3 \pm 0.6$ & $22.8 \pm 0.8$ & 155 & 127 \\
\hline 7 & 306 & 54 & 15 & 0.50 & 1 & 0 & $19.7 \pm 0.4$ & $24.1 \pm 1.2$ & 176 & 134 \\
\hline 8 & 324 & 36 & 10 & 0.45 & 0 & -1 & $17.7 \pm 0.9$ & $25.2 \pm 0.6$ & 158 & 141 \\
\hline 9 & 324 & 36 & 10 & 0.55 & 0 & 1 & $15.0 \pm 1.2$ & $21.4 \pm 1.1$ & 134 & 119 \\
\hline 10 & 360 & 0 & 0 & 0.50 & Con & ture & $11.2 \pm 1.2$ & $17.9 \pm 0.9$ & 100 & 100 \\
\hline
\end{tabular}


Table 5 Chemical compositions of OPC and TWA

\begin{tabular}{lll}
\hline $\begin{array}{l}\text { Chemical } \\
\text { composition } \\
(\%)\end{array}$ & OPC & TWA \\
\hline $\mathrm{CaO}$ & $63.77 \%$ & $36.67 \%$ \\
$\mathrm{SiO}_{2}$ & $17.03 \%$ & $17.44 \%$ \\
$\mathrm{Fe}_{2} \mathrm{O}_{3}$ & $3.46 \%$ & $2.80 \%$ \\
$\mathrm{SO}_{3}$ & $3.30 \%$ & $1.94 \%$ \\
$\mathrm{Al}_{2} \mathrm{O}_{3}$ & $3.23 \%$ & $4.69 \%$ \\
$\mathrm{MgO}$ & $2.65 \%$ & $9.84 \%$ \\
$\mathrm{TiO}_{2}$ & $0.38 \%$ & $0.40 \%$ \\
$\mathrm{~K}_{2} \mathrm{O}$ & $0.21 \%$ & $11.42 \%$ \\
$\mathrm{SrO}$ & $0.10 \%$ & $0.08 \%$ \\
$\mathrm{MnO}$ & $0.05 \%$ & $0.08 \%$ \\
$\mathrm{P}_{2} \mathrm{O}_{5}$ & $0.05 \%$ & $3.10 \%$ \\
$\mathrm{Cl}$ & $0.03 \%$ & $2.55 \%$ \\
$\mathrm{ZnO}$ & $0.02 \%$ & $0.04 \%$ \\
$\mathrm{~V}_{2} \mathrm{O}_{5}$ & $0.02 \%$ & - \\
$\mathrm{CuO}$ & $0.02 \%$ & $0.02 \%$ \\
$\mathrm{Na} 2 \mathrm{O}$ & - & $0.35 \%$ \\
$\mathrm{BaO}$ & - & $0.12 \%$ \\
$\mathrm{ZrO}$ & - & $0.04 \%$ \\
$\mathrm{~L} . \mathrm{O} . \mathrm{I}$ & $5.67 \%$ & $8.41 \%$ \\
\hline & &
\end{tabular}

[25]. It can be observed that TWA contains considerable amounts of $\mathrm{CaO}(36.67 \%), \mathrm{SiO}_{2}(17.44 \%), \mathrm{K}_{2} \mathrm{O}(11.42 \%)$, $\mathrm{MgO}$ (9.84\%), and $\mathrm{Al}_{2} \mathrm{O}_{3}(4.69 \%)$.

The total amount of $\mathrm{SiO}_{2}, \mathrm{Al}_{2} \mathrm{O}_{3}$, and $\mathrm{Fe}_{2} \mathrm{O}_{3}$ in the TWA was $24.93 \%$, which is less than the $70 \%$ minimum to be considered a pozzolanic material [19]. Other researchers have reported agro-waste ash with a total $\mathrm{SiO}_{2}, \mathrm{Al}_{2} \mathrm{O}_{3}$, and $\mathrm{Fe}_{2} \mathrm{O}_{3}$ contents less than $70 \%[12,13,15]$, but even in those cases, it was possible to reach compressive strengths similar to or even greater than $100 \%$ OPC. This is possible because although the ashes are not pozzolanic material, they have pozzolanic activity, but this activity is less than that in pozzolanic material. In addition, the ashes exhibit the "filler effect", which is composed of two phenomena, including the nucleation and packing effects that primarily depend on the fineness of the materials. The nucleation effect occurs when the small particles are spread in blended cement paste, leading to an enhanced hydration reaction, while the packing effect occurs when the voids in pastes are filled with fine particles $[7,12,13]$.

The LOI and $\mathrm{SO}_{3}$ content of TWA were within the limits of 10.0 and 4\%, respectively. This result is important because a high LOI interferes with hydration reactions, reduces workability, and increases the water demand, which affects the final strength and durability of concrete, while the $\mathrm{SO}_{3}$ reacts with $\mathrm{Ca}(\mathrm{OH})_{2}$, causing chemical attack [20].

Based on the TWA chemical composition, it is possible to classify it as a SCM, even though it is not a pozzolanic material.

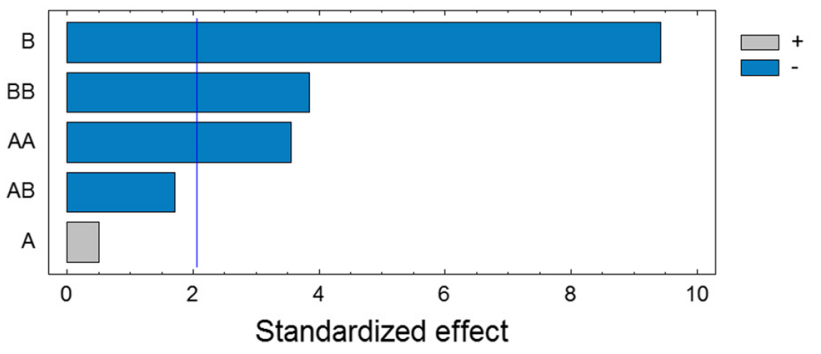

Fig. 1 Pareto chart of standardized effects on compressive strength at 28 days

\section{Compressive strength}

As described previously, the influence of the ash replacement percentage of cement and $w / b$ ratio on the compressive strength at 28 days was tested using a CCD.

The graphic program used to create this figure was Statgraphics Centurion.

ANOVA for the results obtained (Table 4) indicated that three of the five considered factors had a significant effect on the compressive strength at 28 days $(P<0.05)$. The Pareto diagram depicting the comparison of these effects is shown in Fig. 1, where A and B are the ash replacement percentage of cement and the $w / b$ ratio, respectively.

The negative effect of the $w / b$ ratio is because a higher $w / b$ ratio increases the porosity, resulting in a less compact structure and a diminished compressive strength. Despite this result, it is important that a sufficient amount of water is used to accomplish the hydration process and assure adequate workability.

The significant effect of the $w / b$ ratio's quadratic factor occurs because the effect of the variable on the compressive strength at 28 days is not linear within the range studied.

Regarding the ash replacement percentage of cement, there are two effects to consider. The effect of the $A$ quadratic factor is significant, while the effect of the $A$ factor is not significant because the behavior of the variable is not linear within the range studied, and the behavior of the low and high levels is not statistically different.

The interaction effect between the two variables on the compressive strength at 28 days is not significant within the range evaluated.

The following statistical model was obtained from the analysis of the data in Table 4:

$$
\begin{aligned}
& \text { Compressive strength }(\mathrm{MPa}) \\
& \begin{aligned}
= & -168.56+2.93 \times \mathrm{A}+782.25 \times \mathrm{B}-0.07 \times \mathrm{A}^{2}-2.77 \\
& \times \mathrm{AB}-817.14 \times \mathrm{B}^{2} .
\end{aligned}
\end{aligned}
$$




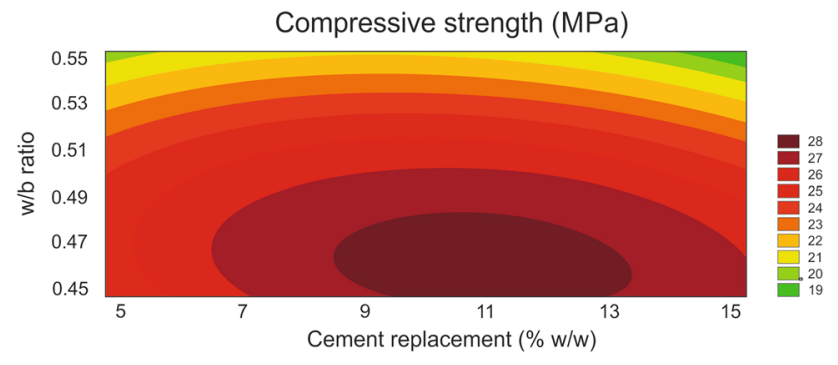

Fig. 2 Contour plot of the CCD indicating the effects of the cement replacement and the $w / b$ ratio on the compressive strength at 28 days

Equation (1) represents $85.4 \%$ of the data variability. The contour plot obtained from Eq. (1) is shown in Fig. 2.

The graphic programs used to create this figure were Statgraphics Centurion and Corel.

According to the results, the optimal compressive strength value lies near the central point of the CCD at the ash replacement percentage of cement and the $w / b$ ratio of $10 \%$ and 0.5 , respectively. Under these conditions, it was possible to achieve compressive strengths that were 86 and $51 \%$ higher than the control mixture (100\% cement) at 7 and 28 days, respectively. The strength gain is possibly due to the filler effect and the additional CSH formation by pozzolanic activity.

These values are similar to those reported by other authors. In the study performed by [12], by replacing $8 \%$ of the cement with organic waste ash, it was possible to obtain compressive strengths that were 17 and $4 \%$ higher than the control mixture at 7 and 28 days, respectively. In [13], by replacing $10 \%$ of the cement with palm oil fuel ash, it was possible to achieve compressive strengths that were 1.3 and $5.7 \%$ higher than the control mixture at 7 and 28 days, respectively. In these studies, the total amounts of $\mathrm{SiO}_{2}, \mathrm{Al}_{2} \mathrm{O}_{3}$, and $\mathrm{Fe}_{2} \mathrm{O}_{3}$ were also less than $70 \%$.

In the studies performed by [14] and [16], a higher percentage of cement could be replaced with ash, possibly because the ashes employed had higher amounts of $\mathrm{SiO}_{2}$, $\mathrm{Al}_{2} \mathrm{O}_{3}$, and $\mathrm{Fe}_{2} \mathrm{O}_{3}$ (Table 3).

\section{Conclusion}

Nowadays, the focus of the research on supplementary cementitious materials (SCMs) is on the exploration of alternative SCMs and their performance in concrete. This is the first report, to the authors' knowledge, using TWA as a SCM. According to the chemical composition, TWA with a particle size of less than $75 \mu \mathrm{m}$ is a promising supplementary cementitious material, even though it is not a pozzolanic material.
The central composite design performed corroborated the negative influence of the $w / b$ ratio on the compressive strength and also the design demonstrated that it is possible to replace $10 \%$ of cement with TWA using a $0.5 \mathrm{w} / \mathrm{b}$ ratio and achieve a compressive strength $51 \%$ higher than the control mixture (100\% cement) at 28 days.

The improvements in the compressive strength were associated with the filler effect and the pozzolanic activity occasioned by the $10 \%$ ash replacement of cement.

The results encourage the use of TWA as a SCM because it can offer greater opportunity for reducing the $\mathrm{CO}_{2}$ emissions from the cement industry making a more sustainable concrete and, additionally, it can valorized an agro waste.

Despite the compressive strength is the most studied property, it is necessary to study the effect of the 10\% TWA replacement of cement in other concrete properties such as slump, bleeding, setting time, and Poisson's ratio.

Acknowledgements The authors acknowledge the financial support from the Organización Gonzalez Bohorquez \& Cia Ltda, the Colombian Department of Science, Technology and Innovation-COLCIENCIAS (Young researcher program in alliance SENA), and the Vicerrectoria de Investigaciones, Universidad de Santander UDES.

\section{Compliance with ethical standards}

Conflict of interest On behalf of all the authors, the corresponding author states that there is no conflict of interest.

Open Access This article is distributed under the terms of the Creative Commons Attribution 4.0 International License (http://creativeco mmons.org/licenses/by/4.0/), which permits unrestricted use, distribution, and reproduction in any medium, provided you give appropriate credit to the original author(s) and the source, provide a link to the Creative Commons license, and indicate if changes were made.

\section{References}

1. CEMBUREAU: Activity report 2016. https://cembureau.eu/media /1635/activity-report-2016.pdf (2016). Accessed 30 Nov 2017

2. Błaszczyński, T., Król, M.: Usage of green concrete technology in civil engineering. Proc. Eng. 122, 296-301 (2015)

3. Pacheco-Torgal, F., Labrincha, J.A.: The future of construction materials research and the seventh UN Millennium development goal: a few insights. Constr. Build. Mater. 40, 729-737 (2013)

4. ASTM C125-16: Standard terminology relating to concrete and concrete aggregates. ASTM International (2016)

5. Amer, A., El-Hoseny, S.: Properties and performance of metakaolin pozzolanic cement pastes. J. Therm. Anal. Calorim. 129, 33-44 (2017)

6. Suraneni, P., Weiss, J.: Examining the pozzolanicity of supplementary cementitious materials using isothermal calorimetry and thermogravimetric analysis. Cem. Concr. Compos. 83, 273-278 (2017)

7. Juenger, M.C.G., Siddique, R.: Recent advances in understanding the role of supplementary cementitious materials in concrete. Cem. Concr. Res. 78, 71-80 (2015) 
8. Rivera, F., Martínez, P., Castro, J., López, M.: Massive volume fly-ash concrete: a more sustainable material with fly ash replacing cement and aggregates. Cem. Concr. Compos. 63, 104-112 (2015)

9. Samad, S., Shah, A., Limbachiya, M.C.: Strength development characteristics of concrete produced with blended cement using ground granulated blast furnace slag (GGBS) under various curing conditions. Sadhana 42, 1203-1213 (2017)

10. Narattha, C., Thongsanitgarn, P., Chaipanich, A.: Thermogravimetry analysis, compressive strength and thermal conductivity tests of non-autoclaved aerated Portland cement-fly ash-silica fume concrete. J. Therm. Anal. Calorim. 122, 11-20 (2015)

11. Akkarapongtrakul, A., Julphunthong, P., Thanongsak, N.: Setting time and microstructure of Portland cement-bottom ash-sugarcane bagasse ash pastes. Monatsh. Chem. 148, 1355-1362 (2017)

12. Rahimi, A., Dogmechi, S.F., Daemi, M.R.: Experimental study on utilization of organic waste ash in concrete mixtures. KSCE J. Civ. Eng. 22, 167-173 (2018)

13. Kroehong, W., Damrongwiriyanupap, N., Sinsiri, T., Jaturapitakkul, C.: The effect of palm oil fuel ash as a supplementary cementitious material on chloride penetration and microstructure of blended cement paste. Arab. J. Sci. Eng. 41(12), 4799-4808 (2016)

14. Chindaprasirt, P., Rukzon, S.: Strength and chloride resistance of the blended Portland cement mortar containing rice husk ash and ground river sand. Mater. Struct. 48(11), 3771-3777 (2015)

15. Baeza-Brotons, F., Garcés, P., Payá, J., Saval, J.M.: Portland cement systems with addition of sewage sludge ash. Application in concretes for the manufacture of blocks. J. Clean. Prod. 82, 112-124 (2014)

16. Bamaga, S.O., Hussin, M.W., Ismail, M.A.: Palm oil fuel ash: promising supplementary cementing materials. KSCE J. Civ. Eng. 17(7), 1708-1713 (2013)

17. Kathirvel, P., Saraswathy, V., Karthik, S.P., Sekar, A.S.S.: Strength and durability properties of quaternary cement concrete made with fly ash, rice husk ash and limestone powder. Arab. J. Sci. Eng. 38, 589-598 (2013)

18. Martirena, F., Monzó, J.: Vegetable ashes as supplementary cementitious materials. Cem. Concr. Res. (2017). https://doi. org/10.1016/j.cemconres.2017.08.015
19. ASTM C618-15: Standard specification for coal fly ash and raw or calcined natural pozzolan for use in concrete. ASTM International (2015)

20. Luna, Y., Arenas, C.G., Cornejo, A., Leiva, C., Vilches, L.F., Fernández-Pereira, C.: Recycling by-products from coal-fired power stations into different construction materials. Int. J. Energy Environ. Eng. 5, 387-397 (2014)

21. MinAgricultura: Cadena de tabaco: Indicadores e Instrumentos, Junio 2016. https://sioc.minagricultura.gov.co/Tabaco/Docum entos/002\%20-\%20Cifras\%20Sectoriales/Cifras\%20Sectoria les\%20-\%202016\%20Junio.pdf (2016). Accessed 30 Nov 2017

22. Departamento Administrativo Nacional de Estadística-DANE: Metodología general Tercer Censo Nacional Agropecuario 3er CNA, 2016. https://www.dane.gov.co/files/investigaciones/ficha s/agropecuario/metodologia_CNA-01_V1.pdf (2016). Accessed 30 Nov 2017

23. Ramesh, S.T., Gandhimathi, R., Nidheesh, P.V., Rajakumar, S., Prateepkumar, S.: Use of furnace slag and welding slag as replacement for sand in concrete. Int. J. Energy Environ. Eng. 4, 3 (2013)

24. Aprianti, E., Shafigh, P., Bahri, S., Farahani, J.N.: Supplementary cementitious materials origin from agricultural wastes-a review. Constr. Build. Mater. 74, 176-187 (2015)

25. ASTM C150/C150M-17: Standard specification for Portland cement. ASTM International (2017)

26. ASTM C33/C33M-16: Standard specification for concrete aggregates. ASTM International (2016)

27. ASTM C188-15: Standard test method for density of hydraulic cement. ASTM International (2015)

28. ASTM C31/C31M-15a: Standard practice for making and curing concrete test specimens in the field. ASTM International (2015)

29. ASTM C39/C39M-16b: Standard test method for compressive strength of cylindrical concrete specimens. ASTM International (2016)

Publisher's Note Springer Nature remains neutral with regard to jurisdictional claims in published maps and institutional affiliations. 